\title{
Detection and enumeration of Staphylococcus aureus from bovine milk samples by real-time polymerase chain reaction
}

\author{
B. G. Botaro, ${ }^{*}$ C. S. Cortinhas, $†$ L. V. Março,† J. F. G. Moreno, † L. F. P. Silva,† N. R. Benites, ${ }^{*}$ \\ and M. V. Santost ${ }^{1}$ \\ *Department of Preventive Veterinary Medicine and Animal Health, and \\ †Department of Animal Sciences, School of Veterinary Medicine and Animal Sciences, University of São Paulo, 13635-900 Brazil
}

\begin{abstract}
The aim of this study was to develop and evaluate a real-time quantitative PCR (qPCR)-based method to detect and quantify Staphylococcus aureus in bronopolpreserved milk samples from subclinical intramammary infections (IMI). Serial dilutions of milk artificially inoculated with Staph. aureus ATCC 29213 were used to establish a standard curve $(\mathrm{cfu} / \mathrm{mL})$ of the $\mathrm{qPCR}$ assay targeting the Staph. aureus thermonucleaseencoding gene nuc according to the strain plate count. The analytical sensitivity, specificity, and repeatability of the qPCR assay were determined. A total of 60 milk samples, collected from mammary quarters without abnormal appearance and with positive isolation of Staph. aureus, were submitted to both the qPCR protocol and Staph. aureus plate counting and results from both methods were compared. Staphylococcus aureus from bronopol-preserved, subclinical IMI milk samples were not accurately enumerated by qPCR compared with plate counting of the nonpreserved, raw milk sample. The detection limit of the qPCR protocol of inoculated Staph. aureus ATCC 29213 in bronopol-preserved milk samples was $1.04 \times 10^{1} \mathrm{cfu} / \mathrm{mL}$. The $\mathrm{qPCR}$ protocol can be a high-throughput and rapid diagnostic assay to accurately detect Staph. aureus IMI from bronopolpreserved milk samples compared with a traditional culturing method. However, the proposed qPCR protocol is not accurate for counting of Staph. aureus in bronopol-preserved milk samples from naturally infected mammary glands.
\end{abstract}

Key words: intramammary infection, dairy cow, bacteria

\section{INTRODUCTION}

Staphylococcus aureus is the most commonly isolated contagious organism from mastitic bovine mammary glands worldwide (Boss et al., 2011). The pathogen

Received January 8, 2013.

Accepted July 16, 2013.

${ }^{1}$ Corresponding author: mveiga@usp.br causes predominantly subclinical IMI (Radostits et al., 2007), resulting in increased SCC and decreased milk production (Blowey and Edmondson, 2010). The standard method of diagnosing mastitis caused by Staph. aureus is microbiological culturing of milk from the infected quarter (Oliver et al., 2004). However, this procedure is time consuming when processing a large number of samples (Koskinen et al., 2009; Taponen et al., 2009) and not sufficiently sensitive to detect the pathogen in mammary quarters with intermittent shedding (Phuektes et al., 2001) or low shedding during lactation (Taponen et al., 2009). Polymerase chain reaction-based methods to detect mastitis pathogens have proven capable of overcoming these limitations (Phuektes et al., 2001; Koskinen et al., 2009; Taponen et al., 2009).

Although SCC determined from nonaseptically collected, bronopol-preserved milk samples has been widely used as a tool to indirectly diagnose mastitis at the cow level (Blowey and Edmondson, 2010), the culturing of mastitis pathogens from the same sample is not possible because of the inhibitory action of the preservative (Sešķēna and Jankevica, 2007). A rapid, highly sensitive, and specific method to detect and enumerate Staph. aureus at the level of the individual animal in bronopol-preserved milk samples has not yet been developed.

The objectives of this study were to determine the diagnostic and analytical sensitivity, specificity, and repeatability of a real-time quantitative PCR (qPCR)based protocol to detect and quantify Staph. aureus in aseptically collected, bronopol-preserved milk samples compared with microbial culture for the diagnosis and enumeration of mastitis caused by Staph. aureus.

\section{MATERIALS AND METHODS}

\section{Preparation of Standards for the qPCR Protocol and Reference Methods}

To prepare standard curves to quantify Staph. aureus and bovine somatic cells, bovine raw milk aseptically 
obtained from a healthy primiparous Holstein cow was used as the dilution medium. The milk had a low total bacterial count $(2,000 \mathrm{cfu} / \mathrm{mL}$ of noncontagious, environmental microorganisms) and a low SCC $(22,000$ cells $/ \mathrm{mL}$ ). No growth of Staph. aureus or any mastitiscausing bacteria (Oliver et al., 2004) was detected, and no amplification of the nuc gene by standard PCR (Kim et al., 2001) was observed in the milk samples used as diluent for the preparation of the standards. At this stage, no preservatives were added to milk.

Staphylococcus aureus. Staphylococcus aureus ATCC 29213 (American Type Culture Collection, Manassas, VA) kept at $20^{\circ} \mathrm{C}$ in a brain-heart infusion broth (BHI; Merck, Darmstadt, Germany) with $50 \%$ glycerol at a concentration of $10^{8}$ to $10^{10} \mathrm{cfu} / \mathrm{mL}$ (Cameotra, 2007) was used to artificially contaminate the milk. One hundred microliters of the Staph. aureus strain solution was pipetted into $6 \mathrm{~mL}$ of BHI broth and incubated at $37^{\circ} \mathrm{C}$ for $15 \mathrm{~h}$. Turbidity confirmed bacterial multiplication in the broth; $6 \mathrm{~mL}$ was then pipetted into $54 \mathrm{~mL}$ of raw Staph. aureus-free, bovine milk. After mixing, 10 serial 1:10 dilutions of milk artificially inoculated with Staph. aureus were made. From each dilution, 3 aliquots were taken for Staph. aureus quantification by (1) flow cytometry, (2) plate count, and (3) qPCR protocol. Azidiol $(0.15 \%$ chloramphenicol and $3.6 \%$ sodium azide) was added to the aliquots for flow cytometry at a concentration of $160 \mu \mathrm{L}$ per $50 \mathrm{~mL}$ of milk and submitted to flow cytometry quantification of the Staph. aureus ATCC 29213 (Cassoli et al., 2010). One bronopol tablet ( $8 \mathrm{mg}$ of 2 -bromo2-nitropropane-1, 3-diol and $0.3 \mathrm{mg}$ of natamycin each; Microtabs II, D\&F Control Systems Inc., Norwood, MA) was added to the aliquot used for qPCR. No preservatives were added to the aliquots used for plate counting.

Viable cell counts of Staph. aureus ATCC 29213 at each dilution were performed by plating $1.0 \mathrm{~mL}$ onto a 3M Petrifilm Staph Express Plate Count (3M, Minneapolis, MN) as recommended by the manufacturer. Plates on which no Staph. aureus ATCC 29213 growth $(0 \mathrm{cfu} / \mathrm{mL})$ was detected were used to establish the analytical sensitivity of the qPCR protocol. Enumeration of Staph. aureus ATCC 29213 by flow cytometry was carried out using the BactoScan flow cytometer (Foss Electric, Hillerød, Denmark) to create reference values for the serial dilutions of Staph. aureus ATCC 29213 in milk, both for the standard plate count (based on enumeration of viable organisms in the sample) and for the qPCR method (based on the total counts of the target DNA).

Somatic Cells. For the SCC quantification curve, $1,000 \mathrm{~mL}$ of a milk sample with a high $\operatorname{SCC}(8,480$ $\times 10^{3} \mathrm{SC} / \mathrm{mL}$ ) was obtained from a hand-milked mul- tiparous Holstein cow. To obtain varying levels of SCC, bovine raw milks with high $\left(8,480 \times 10^{3}\right.$ cells $\left./ \mathrm{mL}\right)$ and low SCC $\left(25 \times 10^{3}\right.$ cells $\left./ \mathrm{mL}\right)$ were proportionately combined to obtain 9 different dilutions of somatic cells $\left(\mathbf{S C} ; 25 \times 10^{3} ; 371 \times 10^{3} ; 897 \times 10^{3} ; 1,550 \times\right.$ $10^{3} ; 2,080 \times 10^{3} ; 2,560 \times 10^{3} ; 2,800 \times 10^{3} ; 5,660 \times$ $10^{3}$, and $8,480 \times 10^{3}$ cells $/ \mathrm{mL}$ ). From each dilution, two 50-mL aliquots were taken for SCC determination by an automated, flow cytometric method (Somacount 300, Bentley Instruments Inc., Chaska, MN) and by the qPCR protocol. One bronopol tablet (Microtabs II, D\&F Control Systems Inc.) was added to each aliquot.

\section{Detection and Quantitation by $q P C R$}

Primers. The primers for Staph. aureus qPCR reactions (F: 5'-CCTGAAGCAAGTGCATTTACGA-3' and R: 5'-CTTTAGCCAAGCCTTGACGAACT-3'; Graber et al., 2007) targeted the Staph. aureus nuc gene (SAU) and yielded a 166-bp amplicon. Primers for bovine somatic cell qPCR reactions targeting the bovine mitochondrial cytochrome $b$ encoding region (BMCB; GenBank accession no. V00654; F: 5'-GCAATACACTACACATCCGACACAA-3' and R: 5'-GCGTGTATGTATCGGATGATTCAG-3') were specifically designed for qPCR (PrimerExpress, Applied Biosystems, Foster, $\mathrm{CA}$ ) and yielded a 98-bp amplicon. This single-copy, low-mutation-rate gene (Hassanin and Douzery, 1999) was chosen as a positive control. Using the PrimerBLAST software (National Center for Biotechnology Information, National Library of Medicine, Bethesda, MD; http://www.ncbi.nlm.nih.gov/tools/primer-blast/ index.cgi?LINK_LOC=BlastHome), the primers for Staph. aureus were checked for annealing specificity among the primer set SAU and the genomic sequences found for Staph. aureus and other staphylococcal species; the primers for bovine SC were checked among the primer set BMCB and genomic sequences found for bovines.

qPCR Simplex Reactions. Every simplex reaction (targeting either SAU or BMCB in different reaction vials) was performed in duplicate (StepOne, Applied Biosystems). Reactions were prepared as recommended by the manufacturer, with the following modifications: each amplification reaction was composed of SYBR Green I PCR Master Mix (Applied Biosystems), 20 pmol of the primer set (SAU or BMCB), and $1 \mu \mathrm{L}$ of nucleic acids extracted directly from the milk samples by a commercially available protocol (QIAamp Spin Procedure, QIAamp DNA Blood Mini Kit, Qiagen Inc., Minneapolis, MN) with modifications: milk sample $(200 \mu \mathrm{L})$ was added to proteinase $\mathrm{K}(20 \mu \mathrm{L}$, provided in the kit) into 1 standard $1.5-\mathrm{mL}$ microcentrifuge tube and homogenized. Lysis buffer $(200 \mu \mathrm{L}$, provided in 
the kit) was added to the mixture and homogenized. Mixture was incubated for $10 \mathrm{~min}$ at $95^{\circ} \mathrm{C}$ and then absolute ethanol $(200 \mu \mathrm{L})$ was added. After vortexing, the mixture was transferred to a silica-gel membrane column (provided in the kit), and centrifuged for 60 $\mathrm{s}$ at $6,000 \times g$ for the DNA bond at the membrane. Washing buffer $(500 \mu \mathrm{L}$, provided in the kit) was added to the column and then centrifuged (60 s at $6,000 \times$ $g$ ). The second wash procedure was carried with the appropriate washing buffer provided in the kit for this step $(500 \mu \mathrm{L})$ and the column was then centrifuged for 3 min at $20,000 \times g$. A second centrifugation step (1 min at $20,000 \times g$ ) was performed to dry the pellet. The silica column was coupled to a fresh, standard 1.5$\mathrm{mL}$ microcentrifuge tube, and $100 \mu \mathrm{L}$ of the provided elution buffer was added to the retained DNA in the membrane for incubation $\left(5 \mathrm{~min}\right.$ at $\left.20^{\circ} \mathrm{C}\right)$. The eluted DNA was collected after being centrifuged twice $(60 \mathrm{~s}$ at $6,000 \times g)$ and kept at $-20^{\circ} \mathrm{C}$ until further analysis.

The reactions were prepared in 48-well reaction plates (MicroAmp, Applied Biosystems). The thermal cycler program consisted of 50 cycles at $95^{\circ} \mathrm{C}$ for $15 \mathrm{~s}$ and $60^{\circ} \mathrm{C}$ for $1 \mathrm{~min}$, with an initial cycle of $95^{\circ} \mathrm{C}$ for 10 min. In each cycle, the accumulation of PCR products was detected by monitoring the increase in fluorescence of the fluorophore binding to the double-stranded amplicons generated. Subsequently, a melting curve was constructed in the range of $60^{\circ} \mathrm{C}$ to $95^{\circ} \mathrm{C}$ for each targeted genome with its respective primer set. Average melting temperatures $\left(\mathbf{T}_{\mathrm{m}}\right)$ were $74.4^{\circ} \mathrm{C}$ for $\mathrm{SAU}$ and $77.8^{\circ} \mathrm{C}$ for $\mathrm{BMCB}$. The final result of each reaction was expressed in threshold cycles $(\mathbf{C t})$.

Reactions were qualitatively considered positive for both detection and quantification of Staph. aureus (primer annealing to its target) when the coefficient of variation $(\mathrm{CV})$ between the $\mathrm{Ct}$ values of duplicates was $<3 \%$ (Bustin, 2004) $\left(\mathrm{T}_{\mathrm{m}} \mathrm{SAU}=75.4^{\circ} \mathrm{C} \pm \mathrm{SD}\right)$ and when amplification of the bovine somatic cell positive control $\left(\mathrm{T}_{\mathrm{m}} \mathrm{BMCB}=77.8^{\circ} \mathrm{C} \pm \mathrm{SD}\right)$ was achieved. In contrast, samples amplified at $\mathrm{Ct}>44$, with a $\mathrm{CV}$ between the $\mathrm{Ct}$ values of $>3 \%$ and amplification of the positive control sample $\left(\mathrm{T}_{\mathrm{m}} \mathrm{BMCB}=77.8^{\circ} \mathrm{C} \pm \mathrm{SD}\right)$ were qualitatively classified as negative.

\section{Sampling}

To evaluate the proposed qPCR protocol for Staph. aureus detection and quantification and for quantification of SCC in bronopol-preserved milk, 60 mammary quarters were randomly selected from lactating Holstein cows from 2 commercial dairy herds (A and B), in the Pirassununga region, São Paulo, Brazil, in which subclinical Staph. aureus mastitis cases have been previously reported. Herd A had 30 lactating cows and B had 150 lactating cows at the time of this study. Thirty cows from each herd were randomly selected. Then, 1 quarter from each cow was selected. Both herds were milked in herringbone parlors. Pre- and postmilking disinfection were routinely performed on both farms, and no segregation of high-SCC cows was performed on either farm. Cows with clinical mastitis or under treatment for any local or systemic disease were excluded from the trial. Two samples were collected aseptically from the selected quarters. One of the samples was used for microbiological culture and enumeration of Staph. aureus; the other sample was conserved with bronopol and used for detection and quantitation of Staph. aureus by $\mathrm{qPCR}$ and for SCC determination by both qPCR and the reference method.

\section{Microbiological Procedures}

Microbiological culture of Staph. aureus was performed as recommended by the National Mastitis Council (Oliver et al., 2004). Samples in which the pathogen was detected were subjected to plate counting (cfu/ $\mathrm{mL}$ ) by using a Petrifilm Staph Express Plate Count (3M) according to the manufacturer's instructions. For evaluation of the analytical specificity of the qPCR protocol, Escherichia coli, Enterococcus spp., Pseudomonas aeruginosa, Streptococcus agalactiae, Streptococcus dysgalactiae, Streptococcus uberis, 5 isolates of $\mathrm{CNS}$, and 2 isolates of coagulase-positive staphylococci (Staphylococcus hyicus and Staphylococcus intermedius) isolated from mastitis cases were separately incubated in BHI broth (Merck) at $37^{\circ} \mathrm{C}$ for $15 \mathrm{~h}$. As growth was confirmed, the broths were separately inoculated in Staph. aureus-negative raw bovine milk and subjected to DNA extraction (QIAamp DNA Blood Mini Kit, Qiagen Inc.). Each sample of extracted DNA was then subjected to the qPCR protocols previously described.

\section{Statistical Analysis}

Heterogeneity of variance was removed from all quantitative data (enumeration of Staph. aureus and SCC) by $\log _{10}$ transformation. Data were anti- $\log _{10}$-transformed for presentation of the results. The normality of residuals was assessed using the Kolmogorov-Smirnov test with the PROC Univariate command of SAS (version 9.2, SAS Institute Inc., Cary, NC).

Standard Curves. For SCC determination by qPCR, the linear correlation (PROC CORR, version 9.2, SAS Institute) between the BMCB $\mathrm{Ct}$ value of a given sample and its SCC count determined by the flow cytometry method was constructed. Once linearity between these 2 values was found $(P<0.05)$, we established the equation to estimate the concentration 
(cells $/ \mathrm{mL})$ of a given sample $\left(\mathrm{Y}_{0}=\mathrm{a}_{0}+\mathrm{b}_{0} \mathrm{X}_{0}\right)$, based on the BMCB $\mathrm{Ct}$ value $\left(\mathrm{Ct}_{\mathrm{BMCB}}\right)$ obtained by $\mathrm{qPCR}$ (PROC REG, version 9.2, SAS Institute), where $\mathrm{Y}_{0}=$ estimated $\log _{10} \mathrm{SCC} / \mathrm{mL} ; \mathrm{a}_{0}=$ intercept; $\mathrm{X}_{0}=\log _{10}$ $\mathrm{Ct}_{\mathrm{BMCB}}$ resulting from $\mathrm{BMCB} \mathrm{qPCR}$ of the sample; and $\mathrm{b}_{0}=$ slope for $\mathrm{X}_{0}$.

To determine the concentration (cfu/mL) of Staph. aureus ATCC 29213 by qPCR, the linear correlation (PROC CORR, version 9.2, SAS Institute) between the SAU Ct value of a given sample and its plate count $(\mathrm{cfu} / \mathrm{mL})$ and the reference method was constructed. Once linearity was observed between these values $(P<$ 0.05), we established the equation $\left(\mathrm{Y}_{1}=\mathrm{a}_{1}+\mathrm{b}_{1} \mathrm{X}_{1}\right)$ to estimate the concentration $(\mathrm{cfu} / \mathrm{mL})$ of a given sample based on the SAU $\mathrm{Ct}$ value $\left(\mathrm{Ct}_{\mathrm{SAU}}\right)$ determined by qPCR (PROC REG, version 9.2, SAS Institute), where $Y_{1}=$ estimated $\log _{10} \mathrm{cfu} / \mathrm{mL} ; \mathrm{a}_{1}=$ intercept; $\mathrm{X}_{1}=\log _{10}$ $\mathrm{Ct}_{\mathrm{SAU}}$ resulting from $\mathrm{SAU}$ qPCR of the sample; and $\mathrm{b}_{1}$ $=$ slope for $\mathrm{X}_{1}$.

Sensitivity, Specificity, and Repeatability of the $q P C R$ Protocol. The parameters for assessing the analytical sensitivity, specificity, and repeatability of the assay were as described previously (Office International des Épizooties, 2010). The analytical sensitivity of the qPCR method was evaluated using aliquots taken from the 1:10 serial dilutions of Staph. aureus ATCC 29212 used to construct the pathogen standard curve. From the aliquot that yielded $\mathrm{cfu} / \mathrm{mL}=0$ to that classified as slightly below "too numerous to count" (TNTC) by the 3M Petrifilm Staph Express Count Plate, all aliquots were subjected to SAU qPCR. The detection limit for SAU qPCR consisted of the value of the sample classified immediately after the sample with $\mathrm{cfu} / \mathrm{mL}=0$, as determined by the reference method. In contrast, the quantification limit was the highest count $(\mathrm{cfu} / \mathrm{mL})$ of Staph. aureus ATCC 29213 in milk immediately before that of the sample with a TNTC value $(\mathrm{cfu} / \mathrm{mL})$.

Analytical specificity of SAU qPCR was assessed by listing the number of samples inoculated with mastitis pathogens other than Staph. aureus yielding no SAU amplification until the 44th cycle but positive for BMCB qPCR.

Repeatability was assessed by analysis of the variability of $\mathrm{Ct}_{\mathrm{SAU}}$ obtained from 6 samples subjected to the entire qPCR protocol on 2 different days ( 1 and 2) in duplicate (d 1, $\mathrm{A}^{\prime}$ and $\mathrm{A}^{\prime \prime}$; $\mathrm{d} 2, \mathrm{~B}^{\prime}$ and $\left.\mathrm{B}^{\prime \prime}\right)$; the intraassay variation ( $\mathrm{CV} \mathrm{A}$; $\mathrm{CV} \mathrm{B})$ was obtained by calculating the coefficient of variation $(\mathbf{C V})$ of duplicates; the interassay variation (CV 1,2) was determined by calculating the $\mathrm{CV}$ of results obtained from samples analyzed on different days.

Diagnostic Agreement. Given that a single milk sample culture allows up to $75 \%$ sensitivity and $94 \%$ specificity for identification of Staph. aureus mastitis
(Sears et al., 1990), the nonparametric kappa test (Altman, 1991) was used to determine agreement between the microbiological reference procedure and the proposed SAU qPCR protocol. Data from SAU qPCR were classified as having either the presence or absence of the pathogen, regardless of the average Ct between duplicates, provided that quality control $\mathrm{qPCR}$ parameters between duplicates were kept. The $\kappa$ coefficient was determined (Epidat version 3.1, Epidemiological Analysis Software for Tabulated Data, Pan American Health Organization/World Health Organization, Santiago de Compostela, Spain) considering 2 methods of observation (microbiological culture for isolation of Staph. aureus vs. SAU qPCR), 2 categories (presence or absence of Staph. aureus), the number of samples analyzed by both methods, and a $95 \%$ confidence level. The $\kappa$ parameters were used to interpret the coefficient of agreement (Altman, 1991) in cases of significant agreement $(P<0.001)$ between methods and to be able to reject the null hypothesis $(\kappa=0)$.

Agreement Between Methods of Measurement. To assess the agreement between quantitative results for both Staph. aureus quantification and SCC obtained by $\mathrm{qPCR}$ and by the reference methods, the BlandAltman nonparametric test of differences (Bland and Altman, 2010) was used (Analyze-it, Analyze-it Software Ltd., Leeds, UK) for Microsoft Excel (Microsoft Corp., Redmond, WA).

\section{RESULTS}

\section{Standard Curve for SCC by qPCR}

Aliquots of milk with increasing SCC as determined by the flow cytometry method (from $11 \times 10^{3}$ to 8.48 $\times 10^{6}$ cells $/ \mathrm{mL}$, or $\log _{10}$ cells $/ \mathrm{mL} 1.39$ to 3.89 , respectively) were used to calculate the standard curve for the SCC estimate by BMCB qPCR (Figure 1). The results of $\log _{10} \mathrm{Ct}_{\mathrm{BMCB}} / \mathrm{mL}$, based on the $\mathrm{BMCB}$ gene amplification performed on milk aliquots, ranged from 1.31 to 1.24 and were linearly related to results of electronic somatic cell counting $(\mathrm{r}=-0.98, P<0.001)$. The SCC in milk measured by the reference method of SCC ranged from $11 \times 10^{3}$ to $8.4 \times 10^{6}$ cells $/ \mathrm{mL}$.

\section{Standard Curve for Enumeration of Staph. aureus ATCC 29213 by qPCR}

Counts of Staph. aureus ATCC 29213 in the 1:10 serial dilutions in milk by plate counting ranged from 300 to $9.0 \times 10^{6} \mathrm{cfu} / \mathrm{mL}$. Linearity between data from plate count and flow cytometry of Staph. aureus ATCC $29213(\mathrm{r}=0.99, P<0.001)$ and between data from SAU qPCR and flow cytometry $(\mathrm{r}=-0.99, P<0.001)$ 


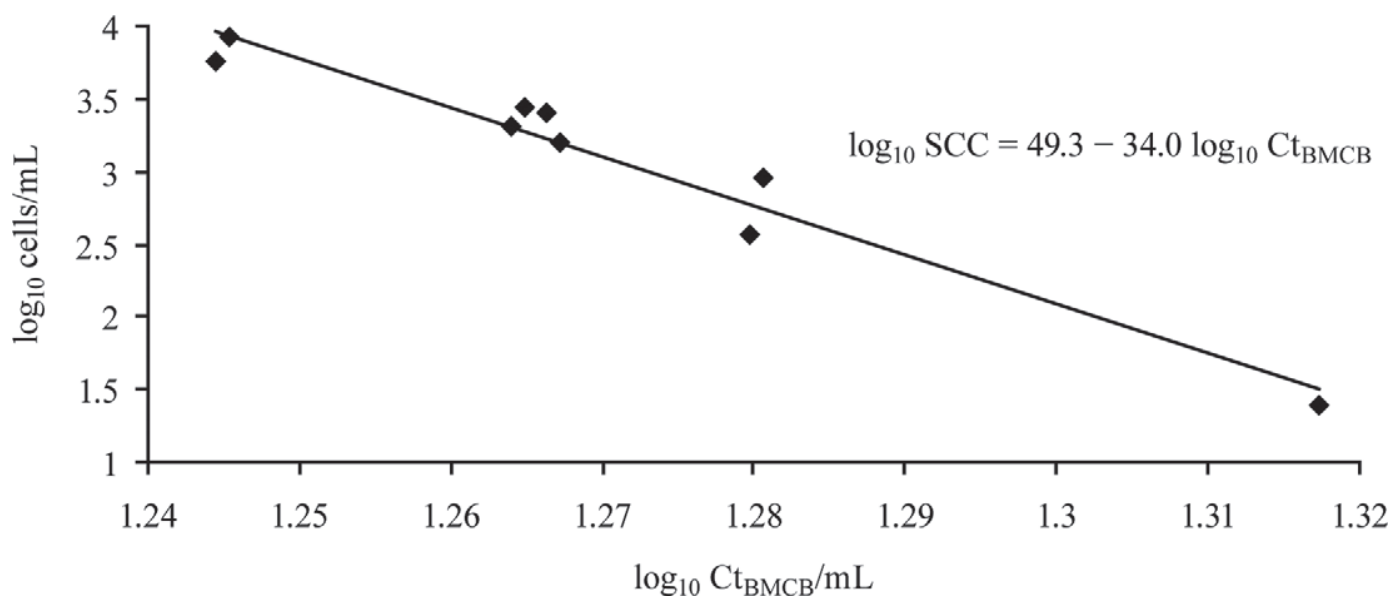

Figure 1. Standard curve of $\log _{10} \mathrm{SCC}$ by real-time quantitative PCR (qPCR) targeting the bovine mitochondrial cytochrome $b$ encoding region (BMCB; specific for bovine somatic cells) as determined by the flow cytometry method $\left(\log _{10}\right.$ cells $\left./ \mathrm{mL}\right)$ and $\mathrm{qPCR}\left(\log _{10} \mathrm{Ct} \mathrm{BMCB}_{\mathrm{BML}} / \mathrm{mL}\right.$ ) $\mathrm{Ct}=$ threshold cycle of the $\mathrm{qPCR}$ reaction.

was observed; a standard curve to estimate Staph. aureus ATCC 29213 levels in milk by SAU qPCR was built (Figure 2). The counts by nuc gene amplification of Staph. aureus ATCC $29213\left(\log _{10} \mathrm{Ct}_{\mathrm{SAU}} / \mathrm{mL}\right)$ ranged from 1.51 to $1.32 \log _{10} \mathrm{cfu} / \mathrm{mL}$ and were linearly related to plate count data $(\mathrm{r}=-0.99, P<0.001)$, which ranged from 300 to $9.0 \times 10^{6} \mathrm{cfu} / \mathrm{mL}$.

\section{Sensitivity, Specificity, and Repeatability of the qPCR Protocol}

The counts from analysis of serial dilutions of Staph. aureus ATCC 29213 in raw milk by SAU qPCR were consistent with the counts from plate counting in the range of $1.04 \times 10^{1} \mathrm{cfu} / \mathrm{mL}$ to $4.2 \times 10^{6} \mathrm{cfu} / \mathrm{mL}$. In all sets of milk artificially inoculated with mastitis-causing pathogens other than Staph. aureus ATCC 29213, the gene encoding the bovine mitochondrial cytochrome $\mathrm{b}$ (BMCB) in bovine somatic cells was amplified, whereas that encoding Staph. aureus nuc was not amplified.

To assess intra- and interassay repeatability of the SAU qPCR protocol, variations of up to $3 \%$ between $\mathrm{Ct}$ values (Table 1) were considered acceptable (Bustin, 2004). Intraassay CV from milk samples with higher Staph. aureus numbers $\left(9 \times 10^{6} \mathrm{cfu} / \mathrm{mL}\right)$ were 0.29 and $1.55 \%$ on $\mathrm{d} 1$ and 2 , respectively. For DNA extraction and $\mathrm{qPCR} n u c$ gene amplification, intraassay CV were 0.25 and $1.72 \%$ (at $1.3 \times 10^{1} \mathrm{cfu} / \mathrm{mL}$ ) on $\mathrm{d} 1$ and 2 , respectively. The $\mathrm{CV}$ of results for protocols carried out on both days was $2.93 \%$ for the milk with $9 \times 10^{6} \mathrm{cfu} /$ $\mathrm{mL}$ of Staph. aureus ATCC 29213 and $2.45 \%$ for the milk with $1.3 \times 10^{1} \mathrm{cfu} / \mathrm{mL}$.

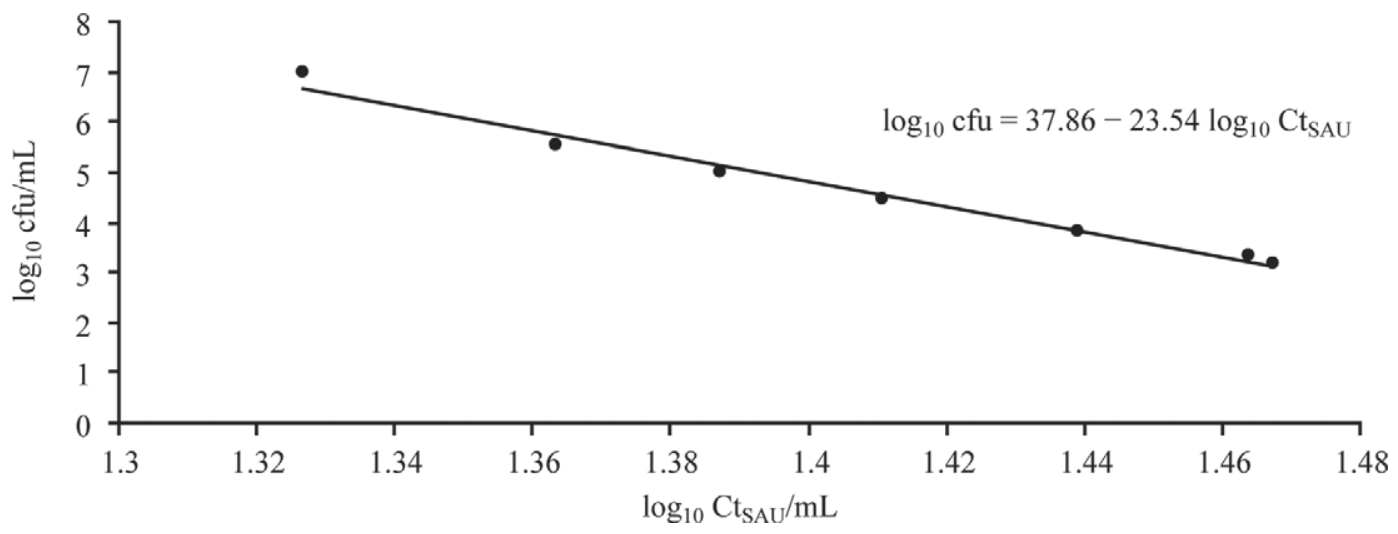

Figure 2. Standard curve of Staphylococcus aureus ATCC 29213 count $\left(\log _{10} \mathrm{cfu} / \mathrm{mL}\right.$ ) as determined by plate counting (log 10 cfu/mL) of nonpreserved, raw milk aliquots and by real-time quantitative PCR (SAU qPCR) targeting the nuc gene of Staph. aureus ( $\log _{10} \mathrm{Ct} \mathrm{SAU}_{\mathrm{SA}} / \mathrm{mL}$ ) of the respective bronopol-preserved samples. $\mathrm{Ct}=$ threshold cycle of the $\mathrm{qPCR}$ reaction. 
Table 1. Coefficients of variation (CV) within and between trials of serially diluted milk samples with decreasing numbers of Staphylococcus aureus subjected to real-time quantitative PCR targeting the nuc gene of Staph. aureus (SAU qPCR) on 2 different days ${ }^{1}$

\begin{tabular}{|c|c|c|c|c|c|c|c|c|}
\hline \multirow[b]{2}{*}{ Sample } & \multirow[b]{2}{*}{ Count $^{2}$} & \multicolumn{3}{|c|}{ Day 1} & \multicolumn{3}{|c|}{ Day 2} & \multirow{2}{*}{$\begin{array}{c}\mathrm{CV} 1,2 \\
(\%)\end{array}$} \\
\hline & & $\mathrm{Ct} \mathrm{A}^{\prime}$ & $\mathrm{Ct} \mathrm{A}^{\prime \prime}$ & CV A (\%) & $\mathrm{Ct} \mathrm{B}^{\prime}$ & Ct B" & CV B $(\%)$ & \\
\hline 1 & $9.0 \times 10^{6}$ & 21.61 & 21.70 & 0.29 & 20.55 & 21.00 & 1.55 & 2.93 \\
\hline 2 & $3.2 \times 10^{5}$ & 23.15 & 23.40 & 0.76 & 23.20 & 22.87 & 1.02 & 0.72 \\
\hline 3 & $3.0 \times 10^{4}$ & 25.91 & 26.18 & 0.74 & 25.50 & 25.44 & 0.16 & 1.58 \\
\hline 4 & $1.4 \times 10^{3}$ & 29.37 & 29.25 & 0.31 & 29.73 & 29.00 & 1.76 & 0.13 \\
\hline 5 & $3.0 \times 10^{2}$ & 32.40 & 32.15 & 0.53 & 32.95 & 32.88 & 0.16 & 1.39 \\
\hline 6 & $1.3 \times 10^{1}$ & 37.25 & 37.12 & 0.25 & 38.97 & 38.03 & 1.72 & 2.45 \\
\hline
\end{tabular}

${ }^{1}$ Independent assays $\mathrm{A}^{\prime}$ and $\mathrm{A}^{\prime \prime}$ and $\mathrm{B}^{\prime}$ and $\mathrm{B}^{\prime \prime}$ were independently performed on $\mathrm{d} 1$ and 2 ; $\mathrm{Ct}=$ threshold cycle in which SAU qPCR occurred; $\mathrm{CV}$ A and $\mathrm{CV}$ B $=\mathrm{CV}$ between $\mathrm{Ct}$ obtained from assays $\mathrm{A}^{\prime}$ and $\mathrm{A}^{\prime \prime}$ and $\mathrm{B}^{\prime}$ and B"; CV 1, 2 = CV between Ct obtained from assays performed on d 1 and 2.

${ }^{2}$ Count $(\mathrm{cfu} / \mathrm{mL}$ ) of Staphylococcus aureus ATCC 29213 as determined by 3M Petrifilm Staph Express Count Plate (3M, St. Paul, MN).

\section{Diagnostic Agreement Between Microbiological Culture and $q P C R$}

Evaluation of agreement between microbiological culture and qPCR for the diagnosis of Staph. aureus in samples of mammary quarters is shown in Table 2. Of the 60 glands analyzed, Staph. aureus was isolated from 43 mammary quarters by microbiological culture and detected by the qPCR method in 44. In no samples did the reference method yield a positive isolation and the qPCR method fail to detect the pathogen. Using microbiological culture as the gold standard, the diagnostic sensitivity and specificity of SAU qPCR were 100 and $97.7 \%$, respectively. The agreement between methods for Staph. aureus detection was $\kappa=0.958(P<0.001)$.

\section{Agreement Between BMCB qPCR and SCC Reference Method}

The SCC data obtained by the automated flow cytometry and by the BMCB qPCR method without deviations between measurements are presented in Figure 3. The magnitude of observed differences between results obtained by flow cytometry and by the BMCB qPCR method (in $\log _{10} \mathrm{SC} / \mathrm{mL}$ ) as a function of the average results obtained by both methods is shown in Figure 6. Although the number of observations was limited, the average difference observed between the results provided by the 2 methods was not significant $(P$ $=0.101)$, with a confidence interval $(95 \% \mathrm{CI})$ ranging from -1.003 to 1.677 . The $95 \%$ CI difference between the limits (0.674) implies an SCC variance of approximately $500 \mathrm{SC} / \mathrm{mL}$ measured by one method (qPCR) and the other (flow cytometry).

\section{Agreement Between qPCR and Staph. aureus Enumeration by the Reference Method}

Data for enumeration of Staph. aureus in milk samples obtained from 43 infected quarters quantified by the reference method (ranging from $3.9 \times 10^{3}$ to $50 \times 10^{3}$ $\mathrm{cfu} / \mathrm{mL}$ ) and estimated by SAU qPCR (ranging from 300 to $250 \times 10^{3} \mathrm{cfu} / \mathrm{mL}$ ) without deviations between measurements are shown in Figure 4.

The magnitude of observed differences (in $\log _{10} \mathrm{cfu} /$ $\mathrm{mL}$ ) between results obtained by the reference method and by SAU qPCR as a function of the average results obtained by both were expected to fall constantly across the identity line and to be approximately normally distributed (Figure 5); however, the large limits of agreement (from -1.852 to 1.188) determined poor agreement $(P=0.0069)$ between methods.

\section{DISCUSSION}

\section{Standard Curve for SCC by qPCR}

The range of SCC values in this study (Figure 1) included values below the threshold for defining subclinical mastitis in mammary glands $(<200,000$ cells $/ \mathrm{mL}$; Schukken et al., 2003) and values close to the quantification limit of the electronic somatic cell counter (IDF, 1995); these findings indicate the robustness of the BMCB qPCR protocol for quantification of bovine somatic cells in bronopol-preserved milk samples. The high linearity $(\mathrm{r}=-0.98, P<0.001)$ observed between SCC determined by qPCR SCC and by flow cytometry allowed us to construct the standard curve $\log _{10}$ SCC $=49.3-34.0 \log _{10} \mathrm{Ct}_{\mathrm{BMCB}}$ for SCC by BMCB qPCR.

Table 2. Frequency of detection of Staphylococcus aureus based on microbiological culture and real-time quantitative PCR (qPCR) in naturally infected quarter milk samples

\begin{tabular}{lccc}
\hline & \multicolumn{2}{c}{ Microbiological culture } & \\
\cline { 2 - 3 } qPCR & Presence & Absence & Total \\
\hline Presence & 43 & 1 & 44 \\
Absence & 0 & 16 & 16 \\
Total & 43 & 17 & 60 \\
\hline
\end{tabular}




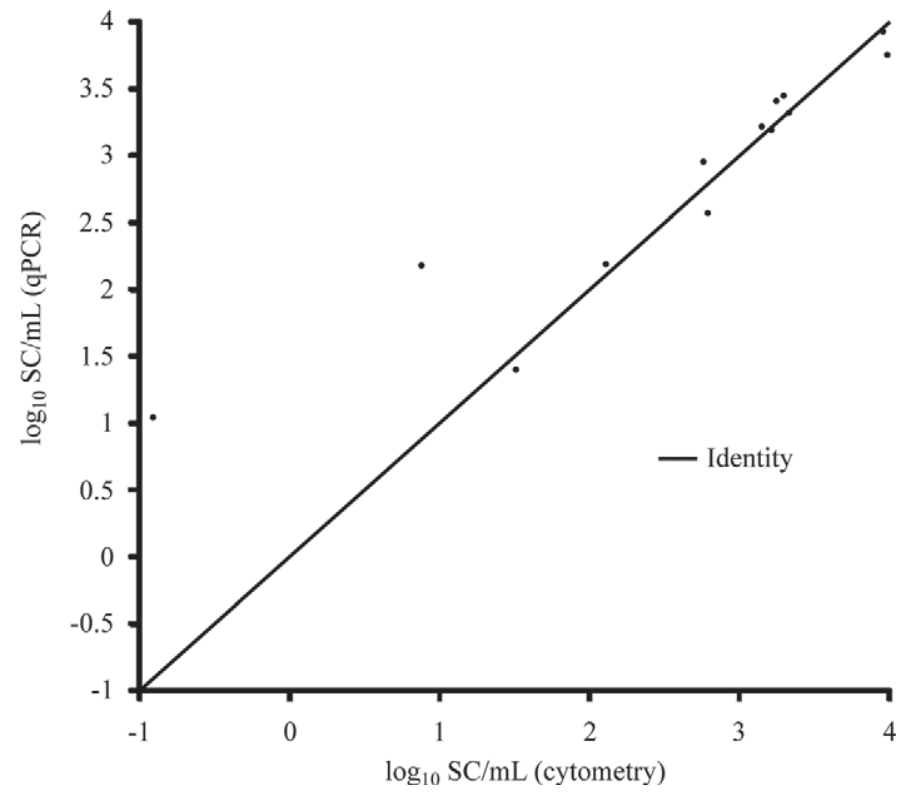

Figure 3. Somatic cell counts $\left(\log _{10} \mathrm{SCC} / \mathrm{mL}\right)$ obtained by realtime quantitative PCR $\left[\log _{10} \mathrm{SC} / \mathrm{mL}(\mathrm{qPCR})\right]$ and the reference method $\left[\log _{10}\right.$ cells $/ \mathrm{mL}$ (cytometry)] plotted on the identity curve.

\section{Standard Curve for Enumeration of Staph. aureus ATCC 29213 by $q P C R$}

Linearity observed between enumeration of Staph. aureus ATCC 29213 by plate count and flow cytometry ( $\mathrm{r}$ $=0.99, P<0.001)$ and between enumeration by $\mathrm{qPCR}$

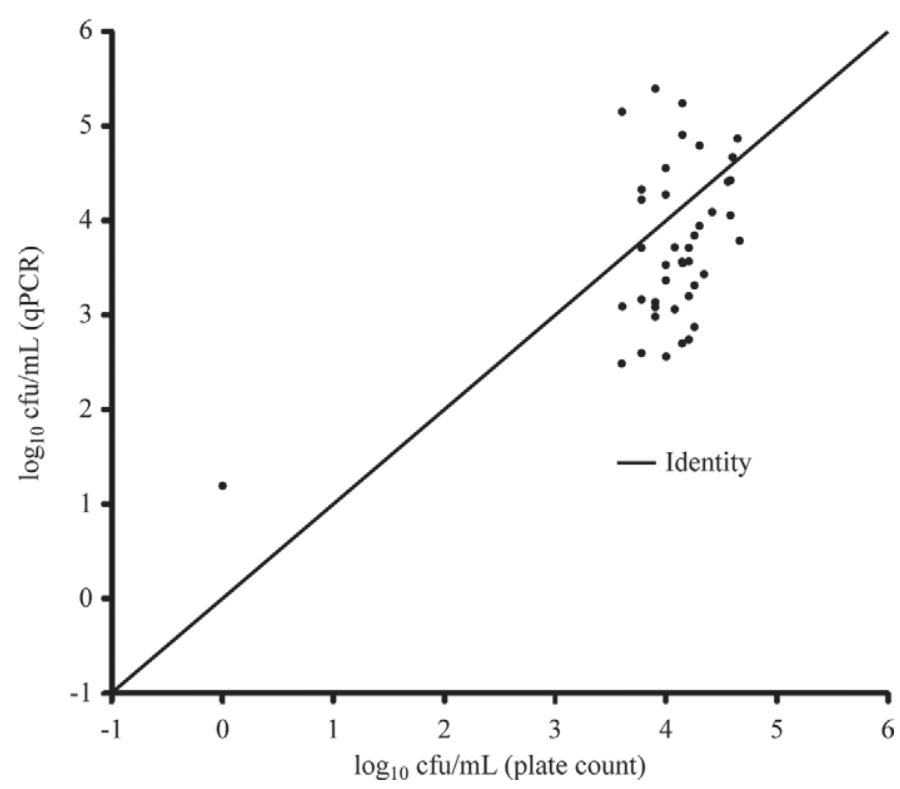

Figure 4. Staphylococcus aureus enumeration $\left(\log _{10} \mathrm{cfu} / \mathrm{mL}\right)$ obtained by real-time quantitative PCR $\left[\log _{10} \mathrm{cfu} / \mathrm{mL}\right.$ (qPCR)] and the plate count reference method $\left[\log _{10} \mathrm{cfu} / \mathrm{mL}\right.$ (plate count)] plotted on the identity curve. and flow cytometry $(\mathrm{r}=-0.99, P<0.001)$ allowed us to construct the curve $\log _{10} \mathrm{cfu}=37.86-23.54 \log _{10}$ $\mathrm{Ct}_{\mathrm{SAU}}$ for SAU qPCR estimation of the count in milk. Hein et al. (2005) and Graber et al. (2007) observed linearities of 0.74 and 0.99 , respectively. Hein et al. (2005), however, estimated the count of Staph. aureus by qPCR based on the number of copies of the nuc gene found in $1 \mathrm{ng}$ of DNA of Staph. aureus DSM 1104 by spectrophotometry. Graber et al. (2007) determined the Staph. aureus equivalent number of cells by qPCR from a serial dilution of purified nuc gene amplicons to construct their standard curve, assuming that nuc was a single-copy gene. Thus, the curve in the present study was different from those obtained by Hein et al. (2005) and Graber et al. (2007), mainly because of differences among preparations used to build the pathogen standard curves.

\section{Sensitivity, Specificity, and Repeatability of the QPCR Protocol}

The qPCR protocol proposed for Staph. aureus detection was consistently reproducible in milk samples with Staph. aureus ATCC 29213 counts as low as $1.04 \times 10^{1} \mathrm{cfu} / \mathrm{mL}$. The nuc gene was chosen for this study because it has only been encountered in Staph. aureus (Fournier et al., 2008) and not in other species

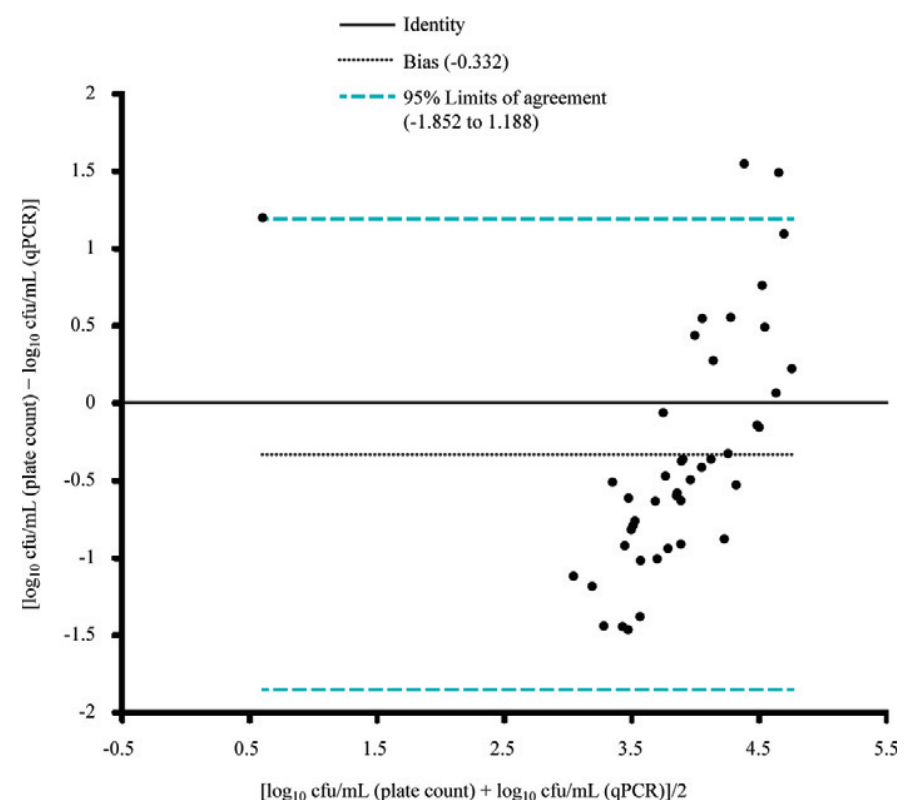

Figure 5. Representative plot of the average of the results of counts $\left(\log _{10} \mathrm{cfu} / \mathrm{mL}\right)$ as a function of the differences observed between both methods [real-time quantitative PCR (qPCR) and plate count]. The bias $(-0.332)$ is the average difference between the values $\left(\log _{10}\right.$ $\mathrm{cfu} / \mathrm{mL}$ ) of both methods. Limits of agreement between the methods ranged from -1.852 to 1.188 . Color version available in the online PDF. 
of coagulase-positive staphylococci (i.e., Staph. hyicus and Staph. intermedius; Graber et al., 2009), thus allowing high analytical specificity of the relevant primer. The Staph. aureus nuc gene has also been described as highly specific of nonhemolytic staphylococcal species (Fournier et al., 2008).

Hein et al. (2005) and Graber et al. (2007) also targeted the nuc gene for Staph. aureus detection; however, their quantitative protocols were performed using the TaqMan System (Applied Biosystems), which increases the diagnostic specificity but can dramatically reduce sensitivity because of gene polymorphisms (Bustin, 2004). Boss et al. (2011) reported an analytical specificity of $100 \%$ using the gene encoding D enterotoxin (sed) to target Staph. aureus in bulk tank milk samples. However, because of the lower prevalence of this genotype among mastitis-causing Staph. aureus, Boss et al. (2011) reported lower diagnostic sensitivity for accurate pathogen detection.

The repeatability of diagnostic tests using the PCR method consists of evaluating the variability of results observed among independently analyzed replicates (after optimization and standardization of procedures for nucleic acid extraction and amplification). The qPCR-based protocol presented in this study showed high repeatability (Office International des Épizooties, 2010) for Staph. aureus ATCC 29213 enumerations ranging from $1.3 \times 10^{1}$ to $9 \times 10^{6} \mathrm{cfu} / \mathrm{mL}$. Because of the low CV observed for those limits, milk samples with counts of Staph. aureus $>9 \times 10^{6} \mathrm{cfu} / \mathrm{mL}$ or $<1.3$ $\times 10^{1} \mathrm{cfu} / \mathrm{mL}$ submitted to the proposed qPCR protocol are likely to show lower repeatability. However, the optimization of the DNA isolation procedure and amplification reactions can overcome this decreasing repeatability (Bustin, 2004).

\section{Diagnostic Agreement Between Microbiological Culture and $q P C R$}

Even though the $\kappa$ coefficient (0.958) indicated almost perfect agreement between the results obtained by microbiological culture and qPCR, we must consider the shortcoming of microbiological culture to detect Staph. aureus from single sampled quarters (Sears et al., 1990; Koskinen et al., 2009; Wellenberg et al., 2010). Using qPCR as a diagnostic tool for subclinical mastitis, some studies reported a higher prevalence of the disease than were reported by microbiological culture (Koskinen et al., 2010; Wellenberg et al., 2010). Wellenberg et al. (2010) reported $24 \%$ more positive samples by qPCR than by microbiological culture. Out of a total of 93 mammary glands analyzed, Koskinen et al. (2010) detected 7 positive samples by qPCR but only 4 by microbiological culture.
The lower predictive validity of negative results obtained by conventional microbiology may compromise actions to control the transmission of Staph. aureus in dairy herds. Thus, considering the diagnostic sensitivity and specificity of the qPCR detection method (100 and $94.12 \%$, respectively), the actual prevalence of Staph. aureus mastitis among quarters would be $73.4 \%$, rather than the prevailing $71.3 \%$ determined by microbiological culture.

\section{Agreement Between BMCB qPCR and SCC Reference Method}

According to Bland and Altman (2010), quantification methods are equivalent if they both use the same scale of measurement and if deviations of the results obtained by the proposed method are not significantly different $(P=0.101)$ from those of the reference method. The BMCB qPCR data obtained were estimated with the equation $\log _{10} \mathrm{SCC}=49.3-34.0 \log _{10} \mathrm{Ct}_{\mathrm{BMCB}}$ and tested for differences (Figure 6), and the 95\% CI resulted from that comparison (equivalent to $\log _{10}$ cells / $\mathrm{mL}=2.7$ ) indicated a difference with little significance for SCC and mastitis epidemiology at the quarter level (Barkema et al., 1997).

Somatic cell count, typically determined by electronic counting, indicates the severity of intramammary inflammation and constitutes a milk quality parameter used worldwide (ISO/IDF, 2006). The SCC results should ideally be combined with those of microbial culture to establish accurate measures of mastitis in dairy herds (Barkema et al., 1997). In the present study, the addition of bronopol to milk samples did not influence the extraction of bovine mitochondrial DNA or generate inhibitors that could affect BMCB qPCR. The target gene used in this study for the quantification of somatic cells in bovine milk did not appear to undergo quantitative variations during the cell cycle of leukocytes, demonstrating its suitability as a positive control and its ability to accurately determine the SCC in samples with SCC ranging from $11 \times 10^{3}$ to $5.66 \times$ $10^{6}$ cells $/ \mathrm{mL}$.

\section{Agreement Between Staph. aureus Enumeration by $q P C R$ and Reference Method}

Although counts of Staph. aureus ATCC 29213 estimated by SAU qPCR and plate count in artificially inoculated milk samples were highly and significantly linearly correlated $(\mathrm{r}=-0.99, P<0.001)$, the count of Staph. aureus in naturally infected milk samples from infected quarters could not be determined by SAU qPCR $(P=0.0069)$. The presence of nonviable or dead Staph. aureus cells present in the milk samples (Barrio 
- Identity

Bias (0.337)

$95 \%$ Limits of agreement $(-1.003$ to 1.677$)$

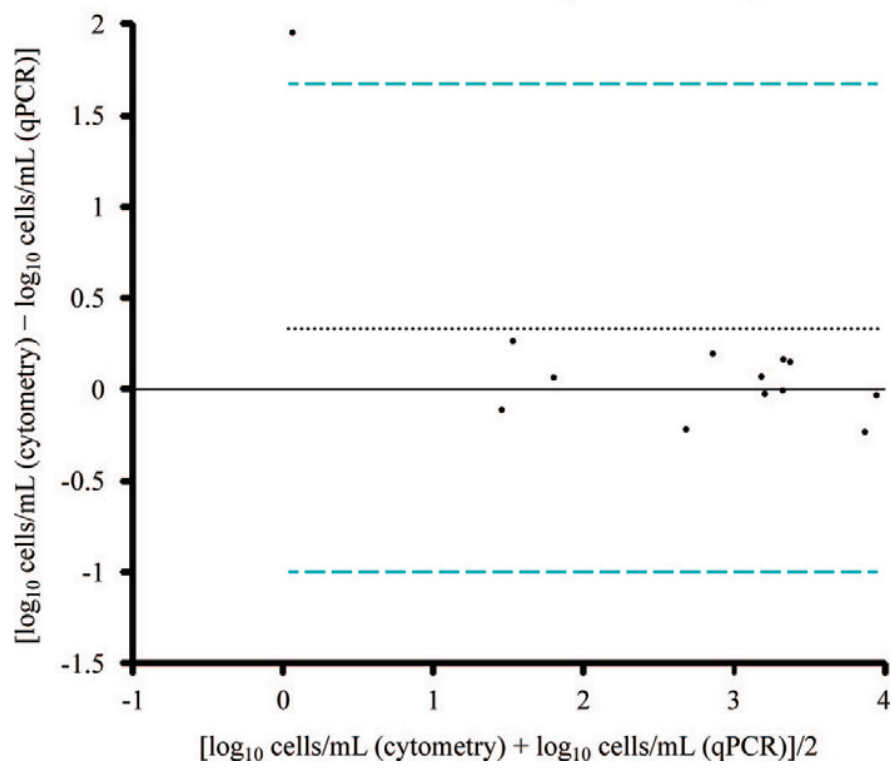

Figure 6. Representative plot of the average of SCC results $\left(\log _{10}\right.$ cells $/ \mathrm{mL}$ ) as a function of the differences observed between the results of both methods [cytometry and real-time quantitative PCR (qPCR)]. The bias $(0.337)$ is the average difference between the values $\left(\log _{10}\right.$ cells $/ \mathrm{mL}$ ) obtained by both methods. The limits of agreement between methods ranged from -1.003 to 1.677 . Color version available in the online PDF.

et al., 2003) was expected to lead to an overestimation of our count by qPCR. Disagreement between qPCR nuc gene enumeration and Staph. aureus plate counting has been reported previously (Hein et al., 2005) and is thought to be related to differences between growth behavior of Staph. aureus strains. An approach to overcome such a discrepancy is to relate the copy number of the target gene to the fluorescence values obtained directly from its amplification (Ludwig and Schleifer, 2000), rather than to its count (in cfu). Another aspect that was not taken into account in our study is the amount of nontargeted DNA of samples, as large amounts are reported to influence qPCR amplification dynamics, leading to underestimation of the targeted DNA (Ludwig and Schleifer, 2000). Moreover, because bronopol used for milk sample preservation (Monardes et al., 1996) possesses a broad spectrum of antibacterial activity (Shepherd et al., 1988) that could hamper PCR-based detectability of the pathogen, the effect of the preservative on Staph. aureus DNA viability should be further investigated.

Graber et al. (2007) found a high correlation between Staph. aureus counts by plate count and $\mathrm{qPCR}(\mathrm{r}=$ $0.92, P<0.001)$. In this study, the interchangeability of methods to enumerate Staph. aureus was assessed by measuring the degree of agreement between them (Bland and Altman, 2010), whereas Graber et al. (2007) used the Pearson product-moment correlation; thus, differences between the statistical approaches could explain the discrepancy between the 2 investigations. Thus, genomic DNA containing the Staph. aureus nuc gene in quantities equal to or higher than the detection limit of this study $(10 \mathrm{cfu} / \mathrm{mL})$ would be detected and quantified by qPCR, regardless of the viability of the pathogen.

The observed mean difference between qPCR (4.1 $\left.\log _{10} \mathrm{cfu} / \mathrm{mL}\right)$ and plate count $\left(3.7 \log _{10} \mathrm{cfu} / \mathrm{mL}\right)$ of $0.4 \mathrm{log}$ units in naturally infected milk samples could also be explained by the differences between counts for different strains of Staph. aureus (Hein et al., 2001). Thus, the regression equation $\log _{10} \mathrm{cfu}=37.86-23.54$ $\log _{10} \mathrm{Ct}_{\mathrm{SAU}}$ based on nuc gene quantification in artificially inoculated milk with Staph. aureus ATCC 29213 is less applicable to the estimate of counts of viable Staph. aureus than it is to the plate count of Staph. aureus in field milk samples. However, because quarters with intermittent, low shedding of the pathogen are a constant source of infection to other cows in the herd (Sears et al., 1990), a quick diagnostic result might represent the main epidemiological advantage of the qPCR protocol over the 48-h minimum time required for a conclusive diagnosis (Oliver et al., 2004) by the traditional method.

\section{CONCLUSIONS}

Analytical specificity of qPCR to detect Staph. aureus was $100 \%$ in milk samples with E. coli, Enterococcus spp., P. aeruginosa, Strep. agalactiae, Strep. dysgalactiae, Strep. uberis, CNS, and coagulase-positive species Staph. hyicus and Staph. intermedius. The detection limit of the qPCR protocol for Staph. aureus ATCC 29213 in milk samples was $1.04 \times 10^{1} \mathrm{cfu} / \mathrm{mL}$. In bronopol-preserved milk samples from subclinically infected mammary quarters, Staph. aureus could be detected but not quantified by the qPCR protocol, because $\mathrm{qPCR}$ did not provide equivalent results to those obtained by the reference method. Therefore, because of its high sensitivity and specificity and its ability to determine SCC from the same sample, qPCR could be adopted as a rapid, high-throughput diagnostic assay to detect Staph. aureus in naturally infected, bronopolpreserved milk samples from subclinically infected mammary quarters.

\section{ACKNOWLEDGMENTS}

This project was supported by São Paulo Research Foundation (FAPESP; Brazil; grant no. 2007/08577- 
3). B. G. Botaro received a scholarship (grant no. 2008/05077-3) from FAPESP during the development of this project. The authors acknowledge Lucinéia Mestieri (Department of Animal Sciences, School of Veterinary Medicine and Animal Sciences, University of São Paulo, Brazil) and Fredi Alexander Díaz Quijano (Department of Epidemiology, School of Public Health, University of São Paulo, Brazil) for their technical assistance.

\section{REFERENCES}

Altman, D. G. 1991. Practical Statistics for Medical Research. Chapman and Hall, London, UK.

Barkema, H. W., Y. H. Schukken, T. J. G. M. Lam, D. T. Galligan, M. L. Beiboer, and A. Brand. 1997. Estimation of interdependence among quarters of the bovine udder with subclinical mastitis and implications for analysis. J. Dairy Sci. 80:1592-1599.

Barrio, M. B., P. Rainard, and B. Poutrel. 2003. Milk complement and the opsonophagocytosis and killing of Staphylococcus aureus mastitis isolates by bovine neutrophils. Microb. Pathog. 34:1-9.

Bland, J. M., and D. G. Altman. 2010. Statistical methods for assessing agreement between two methods of clinical measurement. Int. J. Nurs. Stud. 47:931-936.

Blowey, R., and P. Edmondson. 2010. Mastitis Control in Dairy Herds. 2nd ed. CABI Publisher, London, UK.

Boss, R., J. Naskova, A. Steiner, and H. U. Graber. 2011. Mastitis diagnostics: Quantitative PCR for Staphylococcus aureus genotype B in bulk tank milk. J. Dairy Sci. 94:128-137.

Bustin, S. A. 2004. A-Z of Quantitative PCR. International University Line, La Jolla, CA.

Cameotra, S. S. 2007. Preservation of microorganisms as deposits for patent application. Biochem. Biophys. Res. Commun. 353:849850 .

Cassoli, L. D., G. Francischetti, P. F. Machado, and G. B. Mourao. 2010. The relationship of flow cytometry results with classical measures of bacterial counts in raw refrigerated milk. Int. J. Dairy Technol. 2:297-300.

Fournier, C., P. Kuhnert, J. Frey, R. Miserez, M. Kirchhofer, T. Kaufmann, A. Steiner, and H. U. Graber. 2008. Bovine Staphylococcus aureus: Association of virulence genes, genotypes and clinical outcome. Res. Vet. Sci. 85:439-448.

Graber, H. U., M. G. Casey, J. Naskova, A. Steiner, and W. Schaeren 2007. Development of a highly sensitive and specific assay to detect Staphylococcus aureus in bovine mastitic milk. J. Dairy Sci. 90:4661-4669.

Graber, H. U., J. Naskova, E. Studer, T. Kaufmann, M. Kirchhofer, M. Brechbühl, W. Schaeren, A. Steiner, and C. Fournier. 2009. Mastitis-related subtypes of bovine Staphylococcus aureus are characterized by different clinical properties. J. Dairy Sci. 92:1442-1451.

Hassanin, A., and E. J. P. Douzery. 1999. The tribal radiation of the family Bovidae (Artiodactyla) and the evolution of the mitochondrial cytochrome b gene. Mol. Phylogenet. Evol. 13:227-243.

Hein, I., H. J. Jorgensen, S. Loncarevic, and M. Wagner. 2005. Quantification of Staphylococcus aureus in unpasteurised bovine and caprine milk by real-time PCR. Res. Microbiol. 156:554-563.

Hein, I., A. Lehner, P. Rieck, K. Klein, E. Brandl, and M. Wagner 2001. Comparison of different approaches to quantify Staphylococcus aureus cells by real-time quantitative PCR and application of this technique for examination of cheese. Appl. Environ. Microbiol. $67: 3122-3126$

IDF (International Dairy Federation). 1995. Enumeration of somatic cells. FIL-IDF Standard no. 148A. IDF, Brussels, Belgium.
ISO/IDF (International Organization for Standardization/International Dairy Federation). 2006. Milk-Enumeration of somatic cells. Part 2: Guidance on the operation of fluoro-opto-electronic counters (ISO 13366-2/IDF 148-2:2006). ISO, Geneva, Switzerland.

Kim, C. H., M. Khan, D. E. Morin, W. L. Hurley, D. N. Tripathy, M. Kehrli, A. O. Oluoch, and I. Kakoma. 2001. Optimization of the PCR for detection of Staphylococcus aureus nuc gene in bovine milk. J. Dairy Sci. 84:74-83.

Koskinen, M. T., J. Holopainen, S. Pyörälä, P. Bredbacka, A. Pitkälä H. W. Barkema, R. Bexiga, J. Roberson, L. Sølverød, R. Piccinini, D. Kelton, H. Lehmusto, S. Niskala, and L. Salmikivi. 2009. Analytical specificity and sensitivity of a real-time polymerase chain reaction assay for identification of bovine mastitis pathogens. J. Dairy Sci. 92:952-959.

Koskinen, M. T., G. J. Wellenberg, O. C. Sampimon, J. Holopainen, A. Rothkamp, L. Salmikivi, W. A. van Haeringen, T. J. G. M. Lam, and S. Pyörälä. 2010. Field comparison of real-time polymerase chain reaction and bacterial culture for identification of bovine mastitis bacteria. J. Dairy Sci. 93:5707-5715.

Ludwig, W., and K. Schleifer. 2000. How quantitative is quantitative PCR with respect to cell counts? Syst. Appl. Microbiol. 23:556562.

Monardes, H. G., R. K. Moore, B. Corrigan, and Y. Rioux. 1996. Preservation and storage mechanisms for raw milk samples for use in milk-recording schemes. J. Food Prot. 59:151-154

Office International des Epizooties. 2010. The Animal Health and Production Compendium: Manual of Diagnostic Tests and Vaccines for Terrestrial Animals. Accessed Jan. 4, 2012. http:// www.cabi. org/ahpc/default.aspx? site=160\&page $=3323$.

Oliver, S. P., R. N. Gonzalez, J. S. Hogan, B. M. Jayarao, and W. N. Owens. 2004. Microbiological procedures for the diagnosis of bovine udder infection and determination of milk quality. Natl. Mastitis Counc., Verona, WI.

Phuektes, P., P. D. Mansell, and C. F. Browning. 2001. Multiplex polymerase chain reaction assay for simultaneous detection of Staphylococcus aureus and streptococcal causes of bovine mastitis. J. Dairy Sci. 84:1140-1148.

Radostits, O. M., C. C. Gay, K. W. Hinchcliff, and P. D. Constable. 2007. Diseases of the mammary gland. Pages 699-702 in Veterinary Medicine: A Textbook of the Diseases of Cattle, Sheep, Pig, and Goats. 10th ed. W. B. Saunders, Philadelphia, PA.

Schukken, Y. H., D. J. Wilson, F. Welcome, L. Garrison-Tikofsky, and R. N. Gonzalez. 2003. Monitoring udder health and milk quality using somatic cell counts. Vet. Res. 34:579-596.

Sears, P. M., B. S. Smith, P. B. English, P. S. Herer, and R. N. Gonzalez. 1990. Shedding pattern of Staphylococcus aureus from bovine intramammary infections. J. Dairy Sci. 73:2785-2789.

Sešksēna, R., and L. Jankevica. 2007. Influence of chemical preservatives on the quality and composition indices of raw milk samples. Acta Universitatis Latviensis 723:171-180.

Shepherd, J. A., R. D. Waigh, and P. Gilbert. 1988. Antibacterial action of 2-bromo-2-nitropropane-1,3-diol (bronopol). Antimicrob. Agents Chemother. 32:1693-1698.

Taponen, S., L. Salmikivi, H. Simojoki, M. T. Koskinen, and S. Pyörälä. 2009. Real-time polymerase chain reaction-based identification of bacteria in milk samples from bovine clinical mastitis with no growth in conventional culturing. J. Dairy Sci. 92:26102617.

Wellenberg, G. J., O. C. Sampimon, A. Rothkamp, W. A. van Haeringen, and T. J. G. M. Lam. 2010. Detection of mastitis pathogens by real-time PCR in clinical and subclinical mastitis samples. Pages 539-544 in 5th IDF Mastitis Conf. Proc. Mastitis Research Into Practice, Christchurch, New Zealand. 